\title{
A Case of Anaphylaxis caused by Lemon Sorbet
}

Akiko Naruse, Junko Osako, Daisuke Tsuruta*, Shigeto Yanagihara, Masamitsu Ishii and Hiromi Kobayashi

Department of Dermatology, Osaka City University Graduate School of Medicine, Japan

\section{Introduction}

Citrus fruit is produced and consumed throughout the world, and processed for a lot of food, so we may eat it unconsciously. It is good to know that lemon cause anaphylaxis. We report a case of anaphylaxis caused by lemon.

\section{Case Report}

\section{Patient}

A 17-year-old Japanese woman, without nasal pollen allergy, had been suffering from cashew allergy for 6 years, and lip swelling and oral irritation after eating citrus fruits for 10 years. Moreover, she experienced anaphylaxis at the age of 16 ; when she had eaten a lemon sorbet, played a sousaphone for 45 minutes and walked for 5 minutes, she had noticed swelling of her hands and dyspnea. She had been transferred to the hospital and taken a drip infusion of hydrocortisone, and her systemic symptoms had improved. She came to our hospital to examine whether she had risk of lemon allergy or not because she wanted to participate in the "lemon festival" held in Menton, France.

\section{Allergy tests}

Serum analyses: The patient's total immunoglobulin E (IgE) was $271.0 \mathrm{U} / \mathrm{ml}$, and the results of specific IgE radioallergosorbent tests for orange and grapefruit were Class 2 (lemon was not tested).

\section{Skin tests}

We prepared 3 kinds of fresh citrus fruit (lemon, orange and grapefruit) for skin prick and scratch test $[1,2]$, and then separated raw and heated samples of each. We performed prick-prick method; pricked and coated a Prick-Lancetter (EWO CARE AB, Sweden) with each material, and then pricked her forearm with it. After 15 minutes, we measured the major axis of the wheal $(\mathrm{mm})$. Then we scratched her forearm with the Prick-Lancetter, wiped each material with a cotton swab, and then applied the swab to the scratched line. After 15 minutes, we measured the wheal that formed perpendicular to the line ( $\mathrm{mm}$ ). Histamine dihydrochloride $(10 \mathrm{mg} / \mathrm{ml})$ and physiological saline were used as positive and negative controls, respectively. We defined the wheal as positive when it was larger than $3 \mathrm{~mm}$ or at least half the size of the positive control $[1,2]$.

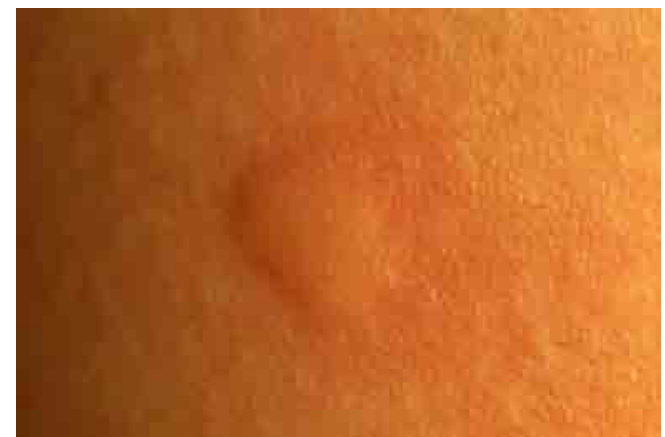

Figure 1: Positive reaction for skin prick test of lemon (heated pulp, wheal diameters: $5 \times 5 \mathrm{~mm}$ )
We did not perform a food challenge to lemon owing to the severity of her reaction.

\section{Outcomes}

Skin prick test showed positive on lemon (heated pulp) (Figure 1), orange (raw pulp), and grapefruit (heated peel), and skin scratch test showed positive on lemon (raw pulp, heated peel), orange (heated pulp) (Table 1).

\section{Diagnosis}

We diagnosed this case as anaphylaxis caused by lemon. And we also diagnosed as oral allergy syndrome caused by citrus fruits, because she had been suffering from lip swelling after eating citrus fruits. We recommended her to avoid ingestion of citrus fruits and their products, and an allergic reaction never happened. Many crushed citrus fruits were known to present at the festival, so we recommended that she does not participate.

\section{Discussion}

Citrus allergy has been reported for orange [3-5], mandarin [6] and grapefruit [7]. Most of citrus allergy has been reported from Europe and America because they consumed more citrus fruits. Zuidmeer et al. [8] reported that the prevalence of perceived allergy to any fruits varied from 0.4 to $6.6 \%$ in adults and 2.2 to $11.5 \%$ in children, and $6.8 \%$ of young children ( $<3$ years) in Norway showed perceived

\begin{tabular}{|c|c|c|c|c|c|c|}
\hline \multirow[t]{3}{*}{ Material } & \multicolumn{2}{|c|}{ Concentration } & \multicolumn{2}{|c|}{ Raw } & \multicolumn{2}{|c|}{ Heated } \\
\hline & & & Prick & Scratch & Prick & Scratch \\
\hline & & & $\begin{array}{l}\text { Wheal } \\
(\mathrm{mm} \times \mathrm{mm})\end{array}$ & $\begin{array}{l}\text { Wheal } \\
(\mathrm{mm})\end{array}$ & $\begin{array}{l}\text { Wheal } \\
(\mathrm{mm} \times \mathrm{mm})\end{array}$ & $\begin{array}{l}\text { Wheal } \\
(\mathrm{mm})\end{array}$ \\
\hline \multicolumn{2}{|c|}{$\begin{array}{l}\text { Histamine dihydro- } \\
\text { chloride }\end{array}$} & $10 \mathrm{mg} / \mathrm{ml}$ & $7 \times 7$ & NT & NT & NT \\
\hline \multicolumn{2}{|c|}{ Physiological saline } & as is & $1 \times 1$ & 0 & NT & NT \\
\hline \multirow[t]{2}{*}{ Lemon } & Pulp & as is & $1 \times 1$ & 3 & $5 \times 5$ & NT \\
\hline & Peel & as is & $1 \times 1$ & 2 & $2 \times 2$ & 4 \\
\hline \multirow[t]{2}{*}{ Orange } & Pulp & as is & $4 \times 4$ & NT & $1 \times 1$ & 4 \\
\hline & Peel & as is & $2 \times 2$ & 2 & $1 \times 1$ & 1 \\
\hline \multirow[t]{2}{*}{ Grapefruit } & Pulp & as is & $1 \times 1$ & 0 & $3 \times 2$ & 0 \\
\hline & Peel & as is & $1 \times 1$ & 0 & $5 \times 4$ & NT \\
\hline
\end{tabular}

NT: not tested

Table 1: Skin prick and scratch test results at 15 minutes.

*Corresponding author: Daisuke Tsuruta, Department of Dermatology, Osaka City University Graduate School of Medicine, 1-4-3 Asahimachi, Abeno-ku, Osaka 545-8585, Japan, Tel: +81 66645 3826; Fax: +81 66645 3828; E-mail: dtsuruta@med.osaka-cu.ac.jp

Received November 29, 2011; Accepted February 20, 2012; Published February 25, 2012

Citation: Naruse A, Osako J, Tsuruta D, Yanagihara S, Ishii M, et al. (2012) A Case of Anaphylaxis caused by Lemon Sorbet. J Aller Ther 3:112. doi:10.4172/2155 6121.1000112

Copyright: ( 2012 Naruse A, et al. This is an open-access article distributed unde the terms of the Creative Commons Attribution License, which permits unrestricted use, distribution, and reproduction in any medium, provided the original author and source are credited. 
Citation: Naruse A, Osako J, Tsuruta D, Yanagihara S, Ishii M, et al. (2012) A Case of Anaphylaxis caused by Lemon Sorbet. J Aller Ther 3:112. doi:10.4172/2155-6121.1000112

Page 2 of 2

with a history of food hypersensitivity in Northern Europe by using questionnaire. In Eastern countries, 9.2\% of patients answered they elicited severe symptoms by lemon, which is rarer in Western countries [9].

In general, lemon sorbet is made from lemon juice and peel. In this case, skin tests were positive for raw and heated lemon and other citrus fruit, so its allergen may be heat-stable allergens common to citrus fruit. One of the lemon allergens has been identified as Cit 13, lipid transfer proteins. Cit 13 and orange allergen, Cit s 3 show very similar molecular masses and $\mathrm{N}$-terminal amino acid sequences [3]. It has been reported that lipid transfer protein of orange accumulated in both pulp and peel, but the latter shows a stronger reaction. We usually peel citrus fruit and eat the pulp. Therefore, the allergic response is thought to be rare and mild [3]. However, we suppose in this case that skin prick and scratch test showed a stronger reaction to lemon pulp than to peel, causing severe allergic responses and inducing anaphylaxis. We estimated that lemon allergen for the patient is heat-stable allergen such as lipid transfer proteins although not proven.

The patient had a cashew nut allergy. The allergens of cashew nuts are seed storage proteins [10], and, to our knowledge, cross-reactivity of cashew and lemon was not reported. The exported lemons always bear preservatives on the peel for long-distance transport. We did not examine the possible association of the preservatives about this patient. However, skin prick and scratch test showed a stronger reaction to lemon pulp than to peel, so we thought the preservatives did not affect lemon allergy in this patient.

Some cases of food-dependent exercise-induced anaphylaxis have been reported for orange and grapefruit [7]. Although the patient developed anaphylaxis after eating lemon sorbet, playing a sousaphone and walking, we cannot define this case as food-dependent exercise-induced anaphylaxis or exercise-unrelated food allergy so far. Accumulative reports of similar cases will be helpful.

\section{References}

1. EAACI (1989) Skin tests used in type 1 allergy testing position paper. Subcommittee on skin tests of the European academy of allergology and clinical immunology. Allergy 44: 1-59.

2. Yagami A, Matsunaga K (2008) Actual methods of skin tests. Arerugi 57: 513 518.

3. Ahrazem O, Ibanez MD, Lopez-Torrejon G, Sanchez-Monge R, Sastre J, et al. (2005) Lipid transfer proteins and allergy to oranges. Int Arch Allergy Immuno 137: $201-210$

4. Ahrazem O, Ibanez MD, Lopez-Torrejon G, Sanchez-Monge R, Sastre J, et al (2006) Orange germin-like glycoprotein Cit s 1: an equivocal allergen. Int Arch Allergy Immunol 139: 96-103.

5. Lopez-Torrejon G, Ibanez MD, Ahrazem O, Sanchez-Monge R, Sastre J, et al (2005) Isolation, cloning and allergenic reactivity of natural profilin Cit s 2 , a major orange allergen. Allergy 60: 1424-1429.

6. Ebo DG, Ahrazem O, Lopez-Torrejon G, Bridts CH, Salcedo G, et al. (2007) Anaphylaxis from mandarin (Citrus reticulata): identification of potential responsible allergens. Int Arch Allergy Immunol 144: 39-43.

7. Iwamoto M, Toma S, Nara H, Sato H, Minota S (2005) A case of food-dependent exercise-induced anaphylaxis after grapefruit ingestion. Allergol Int 54: 495.

8. Zuidmeer L, Goldhahn K, Rona RJ, Gislason D, Madsen C, et al. (2008) The prevalence of plant food allergies: a systematic review. J Allergy Clin Immunol 121: $1210-1218$

9. Eriksson NE, Moller C, Werner S, Magnussson J, Bengtsson U, et al. (2004) Self-reported food hypersensitivity in Sweden, Denmark, Estonia, Lithuania and Russia. J Invest Allergol Clin Immunol 14: 70-79.

10. Hasegawa M, Inomata N, Yamazaki H, Morita A, Kirino M, et al. (2009) Clinica features of four cases with cashew nut allergy and cross-reactivity between cashew nut and pistachio. Allergol Int 58: 209-215 